\title{
Military Intervention and Changing Balance of Power in Libya:
}

\section{A Strongman, Russian Mercenaries and Turkish Drones $^{1}$}

\author{
Péter SELJÁN ${ }^{20}$
}

\begin{abstract}
Libya has sunk into chaos since Muammar Gaddafi was deposed by a Westernled military intervention in 2011. Since then, the Libyan crisis has escalated into an internationalised armed conflict, and a major power struggle between Turkey, Qatar, Italy, and Russia, Egypt, France, and the United Arab Emirates. In the last few years, General Khalifa Haftar has become Libya's most prominent military commander, who is now ruling the eastern part of the country, as the head of the Libyan National Army. His military offensive, launched in April 2019, to capture the capital Tripoli forced Turkey to help the UN-backed Government of National Accord to avoid defeat. But Haftar too received additional military support, especially from Abu Dhabi and Moscow. This escalated the conflict even further, spurring Ankara for another, this time more consequential intervention, which was able to change the local balance of power, so diplomatic efforts and the peace process could get another chance.
\end{abstract}

Keywords: Libya, civil war, intervention, balance of power, Turkey, Russia

\section{Introduction}

The internationalisation of Libya's conflict began with the North Atlantic Treaty Organization's 2011 intervention, while in addition, there were also rival interventions by Qatar and the United Arab Emirates to assist Libyan revolutionary militias, though those were less recognised at that time. Libya’s strategic location at the Maghreb, its significant oil and gas reserves and its revolutionary upheaval made Libya's crisis an attractive opportunity for outside actors, while in fact, the country's post-revolutionary decline, increasing fragmentation and state collapse represents an ever-growing international

Supported by the ÚNKP-20-4-I new national excellence program of the Ministry for Innovation and Technology from the source of the National Research, Development and Innovation Fund.

2 PhD candidate, Corvinus University of Budapest, International Relations; e-mail: peter@seljan.hu 
security threat. ${ }^{3}$ It seems that in the middle of this general upheaval, one of the major players, General Khalifa Haftar was not able to become the leader who could defeat the UN-recognised Government of National Accord (GNA) and its forces. He rather serves largely as a proxy for the external actors like Russia, and as such, Haftar has acted deliberately as an obstacle to the much needed stabilisation, up until the end of $2020 .{ }^{4}$

The conflict took an encouraging positive turn in August 2020, when the head of the Tripoli-based GNA, Fayez al-Sarraj announced a ceasefire and called for parliamentary and presidential elections to be held in 2021. Aguila Saleh, speaker of the rival easternbased, pro-Haftar House of Representatives, also called on all parties to adhere to the truce, which could prevent further foreign military intervention in Libya. ${ }^{5}$ Finally, in October, the warring factions have signed an agreement on a permanent ceasefire, after five days of UN-brokered talks in Geneva, which can serve as an important starting point towards potentially long-lasting peace in Libya. ${ }^{6}$ However, this was only partially possible because of previous Turkish intervention on the western side, which tilted the balance of power to the GNA's favour, thus preventing Haftar from marching westwards. ${ }^{7}$

The stabilisation of Libya has key importance for the security of the region and for Europe, partly since the oil-rich nation is a key transit point for migrants heading to the European Union from Africa. However, the Libyan civil war has not received that much attention in recent years that it would deserve. In this paper we summarise the most important developments of the last two years of the conflict (2019-2020), pointing out how the local balance of power changed through the military intervention of Russia and Turkey. In the first part, we give a short introduction of General Khalifa Haftar, as a central player of the conflict. Then we discuss his offensive against Tripoli, the Russian support he received and the Turkish interventions on the side of the internationally recognised government that turned the fight for the capital. In the end, we close our paper with drawing some conclusions.

\section{Who is Haftar?}

After Haftar announced his offensive against Tripoli, the general's name appeared more frequently in the mainstream media, and many news outlets published short profiles and bios on him. According to the BBC, Khalifa Haftar was born in Libya in 1943, and he was one of the group of officers led by Colonel Muammar Gaddafi who staged a coup and

3 Foreign actors involved in Libya include the United Arab Emirates, Egypt, France, Russia, the United States, Saudi Arabia, Sudan, Jordan, Turkey, Qatar and Italy. See Ramy Allahoum, 'Libya’s war: Who is supporting whom’, Al Jazeera, 09 January 2020.

4 Tarek Megerisi, ‘Geostrategic Dimensions of Libya’s Civil War’, Africa Security Brief No 37, May $2020,1-2$.

5 The Guardian, 'UN-supported Libya government and rival authority call ceasefire', 21 August 2020.

$6 \quad$ Nick Cumming-Bruce and Declan Walsh, 'Libya Cease-Fire Raises Hopes for Full Peace Deal', The New York Times, 23 October 2020.

7 By 2015, Libya was practically divided into parts corresponding to the former historical regions (administrative divisions) of the country. The most populous region is Tripolitania in the west with a population of approximately 3.5 million, followed by eastern Cyrenaica with around 1.5 million and the poorest region is Fezzan in the south with a population less than 500 thousand. 
seized power from King Idris in 1969. Then, Haftar oversaw the Libyan forces involved in the conflict in Chad in the 1980s. But as Libya was defeated by the French-backed Chadian forces, Haftar and his few hundred men were captured by the Chadians in 1987. Gaddafi denied the presence of Libyan troops in Chad, and even disowned Haftar, which led the general to devote his time to toppling the Libyan leader. He went into exile in the United States, but during this time, he was in close cooperation with the CIA, which backed him in several attempts to assassinate Gaddafi. After the start of the so-called Arab Spring protests in 2011, Haftar returned to Libya, where he became the commander of the rebels in the east. ${ }^{8}$

As Tarek Megerisi highlighted, the collapse of the General National Congress (GNC) in the Spring of 2014 was a turning point in Libya's transition, symbolised best by the re-emergence of General Haftar who faded into obscurity until February 2014. In 2011, he was quickly sidelined, since many Libyans were unwilling to work with him, deeming him responsible for atrocities committed during the Chadian war of the 1980s. In February 2014, Haftar unexpectedly appeared on TV to outline his plan to save the nation and called on Libyans to revolt against the elected GNC, whose mandate was still valid at the time. According to Megerisi, Haftar's TV announcement represented the beginning of politics by other means in Libya: 'The moving away from politicians employing militias toward a paradigm whereby militias employed politicians to provide a shroud of legitimacy.' Haftar's reintroduction to Libya was backed by Cairo, and while his coup attempt failed to gain support in the capital Tripoli, he quickly provided a new reason for some other actors to cooperate with him over the course of 2014, by launching a war on terror in eastern Libya. $^{9}$

As Jon Lee Anderson of The New Yorker noted, 'Haftar has fought with and against nearly every significant faction in the country's conflicts, leading to a reputation for unrivalled military experience and for a highly flexible sense of personal allegiance'. In Operation Dignity, the Libyan National Army, led by Haftar, has taken much of the eastern half of Libya, while most of the remainder was held by Libya Dawn, a loose coalition of militias. Anderson met with Haftar in person, and the general told him why he had gone back to Libya. After participating in the 2011 uprising against Gaddafi, Haftar tried to find a place for himself in the country's new political landscape. When he did not succeed, he returned to the U.S. from where he watched as Libya floundered under a succession of weak governments, and the country's militias grew more powerful. This turn of events upset Haftar, who soon became the self-declared saviour of Libya. But while Haftar said he was targeting terrorists, his definition of terrorism is way too broad, and many consider him a vigilante. Thus, it is possible that Haftar's vigilantism will motivate those who oppose him to unite, giving a common cause to extremists and non-extremists alike, next to the fight against the Islamic State. One of the main legacies of the history of tribalism in Libya, and partly the decades long rule of Gaddafi, is that things can get settled only by force, which has created a Libyan culture of 'with or against'. ${ }^{10}$

BBC, 'Khalifa Haftar: The Libyan general with big ambitions’, 08 April 2019.

Megerisi, 'Geostrategic Dimensions', 3-4.

Jon Lee Anderson, ‘The Unravelling’, The New Yorker, 16 February 2015. 


\section{Haftar's Tripoli offensive}

As the war on terror gradually ended, Haftar's foreign backers provided him the support needed to extend his reach further to acquire Libya's oil export terminals and to conquer the remainder of eastern Libya. Meanwhile, thanks to his foreign allies, Haftar refused to support the UN-backed Libyan Political Agreement (LPA), which was intended to reunify the country, establishing the Government of National Accord in December 2015, led by a new Prime Minister, Fayez al Sarraj. ${ }^{11}$ This peace process was backed by the United States, the United Kingdom and Italy, hoping that it could end Libya's civil war and create a partner for combatting terrorism and tackling migration. However, as the process dragged on, the crisis just deepened. Sarraj and his government arrived in Tripoli in March 2016, when it has become evident that the GNA lacks real political power, struggled to operate in a city controlled by militias and the international actors quickly abandoned it for more expedient policies. Haftar ultimately declared the Libyan Political Agreement void in December 2017.12 UN Special Representative Ghassan Salame tried to break the diplomatic deadlock during the next two years to create a new, inclusive political process that would lead to a new government and institutions more reflective of Libya's patchwork of political and military actors. However, the new plan remained highly contested with many in Libya refusing to support it, which eroded the credibility of the international actors in the country. Eventually, this led to Haftar trying to seize power by launching a surprise attack on Tripoli in April 2019. ${ }^{13}$ After these, events have accelerated, but it does worth going through the timeline of the next months. ${ }^{14}$

On April 7, GNA forces announced a counter-offensive against Haftar's forces, aimed at 'purging all Libyan cities of aggressor and illegitimate forces'. The Wall Street Journal reported on April 12, that days before Haftar launched the offensive, Saudi Arabia offered tens of millions of dollars to help pay for the operation. The offer, which Haftar accepted, allegedly came during a visit by Haftar to Riyadh, and was intended to buy the loyalty of tribal leaders, recruit and pay fighters, and for other military purposes. ${ }^{15}$ The White House released a statement on April 19, saying that U.S. President Donald Trump recognises Haftar's significant role in fighting terrorism and securing Libya's oil resources, which prompted thousands of people to take to the streets in Tripoli, calling on the international community to stop the military aggression by Haftar's forces. ${ }^{16}$ On May 22, Ghassan Salame, the UN envoy to Libya, denounced the conflict raging in Libya, highlighting that the country has become a textbook example of foreign intervention in local conflicts. ${ }^{17}$ But on May 26, Haftar said in an interview that he will continue fighting until militias in Tripoli laid down their arms, even though his objective is to reach a political solution. ${ }^{18}$

\footnotetext{
Aziz El Yaakoubi, 'Libyan factions sign U.N. deal to form unity government', Reuters, 17 December 2015.

Al Jazeera, ‘Haftar: Libya’s UN-backed government’s mandate obsolete’, 18 December 2017.

Megerisi, 'Geostrategic Dimensions', 4-6.

Al Jazeera, ‘Timeline: Haftar’s months-long offensive to seize Tripoli’, 19 February 2020.

Jared Malsin and Summer Said, 'Saudi Arabia Promised Support to Libyan Warlord in Push to Seize Tripoli', The Wall Street Journal, 12 April 2019.

16 Al Jazeera, 'Trump praises Haftar in apparent reversal of US policy on Libya’, 20 April 2019.

17 Al Jazeera, 'UN envoy: ‘Libya a textbook example of foreign intervention’, 23 May 2019.

18 Al Jazeera, 'Libya’s Haftar vows to fight until Tripoli ‘militias’ defeated’, 26 May 2019.
} 
Haftar's Tripoli offensive and his plan to take power in April 2019 failed eventually, as he found himself confronted by the greatest mobilisation of fighters in the country since the 2011 revolution against Gaddafi.

On June 29, Haftar banned Turkish commercial flights to the GNA and ordered LNA forces to attack Turkish ships and interests in the country, which signalled that the tensions between the GNA-supporter Ankara and Haftar are increasing. On July 1, LNA's air force destroyed a Turkish drone parked at Mitiga International Airport, while Turkey's foreign ministry accused Haftar's forces of seizing six of its citizens. Ankara issued a warning to Haftar, urging him to release the Turkish citizens, or the LNA will become a 'legitimate target'. The warring sides agreed to a temporary truce on August 10, which was proposed by the UN during the Muslim holiday of Eid al-Adha. Eventually, in November, a UN report revealed that the United Arab Emirates, Sudan, Turkey and Jordan have been violating the arms embargo in Libya. ${ }^{19}$ In the middle of November, the U.S. has finally called on Haftar to stop his months-long offensive on Tripoli and said it would back the GNA's forces against Russia's attempts to exploit the conflict. This was the most explicit call by the U.S. against Haftar, who was earlier praised by President Trump. ${ }^{20}$ A week later, on November 23, Haftar declared a 'no-fly zone' in the skies over the capital Tripoli, drawing a warning from the GNA. But the events took a major turn on November 27, when Turkey and Libya signed two agreements on security and military cooperation and restriction of marine jurisdictions. ${ }^{21}$ On December 5, GNA officials announced that they will confront Moscow over the alleged deployment of Russian mercenaries to fight alongside Haftar's forces, saying that they documented between 600 and 800 Russian mercenaries in Libya, while on December 22, Turkish President Recep Tayyip Erdoğan said that Turkey will increase its military support to the GNA if necessary. ${ }^{22}$

Haftar's offensive could not succeed as his forces struggled to maintain long supply lines through territory that they barely controlled. However, after the decision was made to launch the offensive, there were no other choices left for General Haftar and his supporters. He either had to win the conflict and establish himself as the new ruler of Libya, or lose everything, and let a new chapter begin for the country. And this situation mobilised not just Libyans, but foreign actors as well, especially Russia and Turkey. According to Megerisi, Russia has long used the Libyan civil war to advance its relationships with Egypt and the UAE, while simultaneously expanding its influence in the Mediterranean and its access to Libya's natural resources. As he noted, 'Russia pulled a page from its Syria playbook to prop up a weak and isolated authoritarian leader in a conflict most global actors wanted to avoid'. ${ }^{23}$ Libya's destabilisation created opportunities for Russia to increase its influence in the region, and ensuring Moscow played a decisive role in any future political settlement.

\footnotetext{
19 'Final report of the Panel of Experts on Libya established pursuant to Security Council resolution 1973 (2011)', United Nations Security Council, S/2019/914, 09 December 2019.

20 'Joint Statement on U.S.-Libya Security Dialogue', U.S. Department of State, 14 November 2019.

21 Al Jazeera, 'Libya, Turkey sign deals on security and maritime jurisdictions’, 28 November 2019.

22 Al Jazeera, 'Timeline: Haftar’s months-long offensive’.

23 Megerisi, 'Geostrategic Dimensions', 6.
} 


\section{Turkey turns the fight}

Before the Arab Spring, Turkey secured a major share of the construction contracts in Libya. In addition, Ankara and Tripoli had agreed to increase their investments in the energy sector, small and medium-sized enterprises, technology, agriculture and so on. As a result, there were around 25,000 Turkish employees in Libya by 2011, and Turkish investors spent billions of dollars in the construction sector. ${ }^{24}$ In light of its economic interests in Libya, it is understandable why Turkey first opposed the military intervention against Gaddafi in the spring of 2011. But Ankara soon realised that the Turkish position cannot be upheld, thus finally gave in, and supported the Libyan intervention. Up until 2014, Turkey strove to restore its economic relationship with Libya, supported the stabilisation efforts and the establishment of a central government. Ankara supported the Libyan political agreement signed in December 2015, and the establishment of the UN-backed Government of National Accord as well. The Turkish military role supporting the GNA grew as the tension increased on the ground, especially after Haftar's offensive against Tripoli in April 2019. ${ }^{25}$

Since Turkey has long maintained economic interests in Libya, and Haftar's eventual success would cement Emirati and Egyptian influence in North Africa, as long as Haftar has foreign backing and the capabilities to wage war on the GNA, he presents a serious challenge for Turkey in Libya and in the region. For this reason, Haftar's Tripoli offensive forced Turkey to either move against Haftar and his foreign supporters (namely the UAE, Egypt and Russia) to claim Libya, or to let go of the GNA's hand. It also must be noted that this situation provided Turkey an opportunity to advance its economic interests in the eastern Mediterranean. In February 2018, significant gas reserves have been discovered in that area, and a coalition formed between Greece, Cyprus, Israel and Egypt to begin to develop security and economic infrastructure, which Turkey viewed as a direct threat to its economic interests and dominant security role in the region. ${ }^{26}$

Turkey joined the war in May 2019, on the side of the GNA, though its military support in that time was mainly unannounced and clandestine. Turkish military support began to take a public character when the GNA had received a shipment of armoured vehicles and arms after asked its ally Turkey for help. ${ }^{27}$ In June, President Erdoğan announced that Turkey was providing weapons to the GNA under an unspecified military cooperation agreement, and he also added that Ankara's military support allowed Tripoli to 'restore balance' in Libya against Haftar's forces backed by the UAE and Egypt. ${ }^{28}$ But the Turkish military support principally consisted of just a small drone fleet and armoured personnel

24 Ferhat Polat, 'The trajectory of Turkey-Libya relations', TRT World, 30 August 2019.

25 'Turkey’s Growing Role in Libya: Motives, Background and Responses', Arab Center for Research \& Policy Studies, 15 January 2020, 1.

26 Michael Tanchum, 'A dangerous policy of Turkish containment in the Eastern Mediterranean', The Jerusalem Post, 10 July 2019.

27 Reuters, 'Forces loyal to Libya’s U.N.-backed government receive military hardware', 18 May 2019.

28 'Turkey’s Growing Role in Libya’, 1. 
carriers. Thus, the net effect of this equipment on the battle was limited and overall, the Turkish aid was not as decisive nor as substantial as the GNA might have hoped. ${ }^{29}$

While Abu Dhabi, Cairo, Ankara and Doha have been supporting the competing sides of the Libyan conflict from its early stages, the civil war escalated further in the fall of 2019 with the deployment of foreign mercenaries in support of Haftar's forces. By the fall of 2019, diminishing Turkish support had shifted the momentum to the LNA, which was mainly due to the increase of Emirati support and Chinese-designed Wing Loong II combat drones, but also due to yet another foreign intervention into the conflict. In the fall of 2019, hundreds of Russian paramilitary fighters and mercenaries from the Kremlinlinked Wagner Group, arrived to help the LNA forces fighting for the capture of Tripoli, which tilted the balance of the conflict in Haftar's favour. ${ }^{30}$ The Wagner Group fighters took on an increasingly active role in the LNA advance on the capital, supported by the UAE, and as a result of this foreign support, Haftar's forces steadily gained territory in late 2019. At the end of the year, for the first time since the start of the 2019 war, the prospect of an LNA push into central Tripoli appeared as a real possibility. But while facilitating these advances, Russia had inadvertently spurred another round of foreign military intervention in Libya, arguably the most consequential since 2011. ${ }^{31}$

Fearing a potential collapse of its defences around Tripoli, the UN-backed GNA in the late fall of 2019 turned again to Turkey for help. As a result, on November 27, the GNA and Ankara signed two memoranda of understanding relating to security and military cooperation, and the definition of maritime jurisdiction areas, the latter of which was basically a deal on an exclusive economic zone in the eastern Mediterranean that would grant Turkish exploration and drilling rights to offshore hydrocarbon resources. ${ }^{32}$ In return, President Erdoğan promised closer security cooperation and to send military support to the GNA. Two weeks after the activation of the maritime border demarcation agreement, the security and military cooperation agreement with Libya was also approved by the Turkish parliament. ${ }^{33}$ This agreement with Libya was a major power play, which aligned with Turkish strategic goals in the Mediterranean region as well as Turkey's economic penetration into Africa. ${ }^{34}$ More importantly, this agreement significantly transformed the Libyan war, opening a new chapter in the history of the conflict. Turkish military support to the GNA from this point became open and more serious. Turkey so far has sent military advisers, arms and a fleet of 20 drones to defend Tripoli from the forces of Haftar. In addition, according to news reports, Turkey has sent Syrian proxy fighters to Libya. But after the Turkish Parliament approved plans in January to send troops there, the conflict

29 Frederic Wehrey, ‘This War Is Out of Our Hands: The Internationalization of Libya’s Post-2011 Conflicts from Proxies to Boots on the Ground', New America, 11 September 2020, 28.

30 David D Kirkpatrick, 'Russian Snipers, Missiles and Warplanes Try to Tilt Libyan War', The New York Times, 05 November 2019.

31 Wehrey, 'This War Is Out of Our Hands', 29-30.

32 Daren Butler and Tuvan Gumrukcu, 'Turkey signs maritime boundaries deal with Libya amid exploration row’, Reuters, 28 November 2019.

33 'After the maritime agreement ... Turkey announces a new step in military cooperation with Libya', Teller Report, 15 December 2019.

34 Ceyda Caglayan, 'Turkey aims to sign deal with Libya over Gaddafi-era compensation', Reuters, 10 January 2020. 
escalated even further, and has become a chaotic proxy war between multiple powers for control of the oil-rich country. ${ }^{35}$

The proxy forces dispatched by Turkey to Libya in December 2019 comprised an initial part of a few thousand fighters drawn from Turkish-backed Syrian militias, some of whose members had fought in Syria's civil war. These Syrian fighters were delivered by civilian aircraft and ships into Tripoli and Misrata. Many of them were ethnic Turkmen with close familial ties to Turkey, and in return for their service, they were offered huge salaries and the promise of Turkish citizenship. The additional Turkish military support among others consisted of more Bayraktar TB2 drones, sophisticated air defence systems and electronic warfare equipment. Turkey's layered air defence systems effectively negated Haftar's air advantage over Tripoli and Misrata, thus GNA forces around the capital were suddenly afforded greater mobility. A foreign military intervention on this scale can have a decisive effect on the course of the battlefield - as we have seen this already at the fall of Gaddafi -, thus Turkey eventually managed to turn the battle for Tripoli. ${ }^{36}$ However, while the Syrians meant much help, they also stirred some controversy, since some GNA commanders resented the deployment of foreign infantry, arguing that what was really needed was advanced weapons and equipment, not foreign manpower. Still, by creating a new balance between the opposing forces on the frontline, the Turkish intervention with the deployment of Syrian fighters enabled a push by Moscow and Ankara to try and mediate an end to the conflict. ${ }^{37}$

Finally, on January 12, Vladimir Putin, in coordination with Erdoğan, hosted a summit in Moscow that both the GNA prime minister al-Sarraj and Haftar attended, resulting in a commitment to a truce. But only al-Sarraj signed the agreement, because Haftar later walked out of the meeting. Partially motivated by the Moscow summit and the opportunity opened by Haftar's walkout, the European countries finally were able to mobilise and reach a consensus on talks of their own. Right after the Moscow summit, another international conference convened on January 18, hosted by German Chancellor Angela Merkel. In the final communique of the participants, the international parties committed to enforcing the arms embargo and working toward a truce. However, aerial and maritime arms shipments into Libya resumed almost as soon as the peace conference ended. The first months of 2020 thus went by with the build-up and regrouping of the opposing forces, supported by their foreign patrons. After the Berlin conference, the UAE tried to compensate for the Turkish intervention by flying in equipment in heavy aircraft to eastern Libya to beef up Haftar's forces. ${ }^{38}$ Turkey also sent more advisers and officers, self-propelled artillery, radars, tanks and even naval frigates with helicopters, which would eventually be used in a counterattack on Haftar's forces. ${ }^{39}$

35 Carlotta Gall, 'Turkey, Flexing Its Muscles, Will Send Troops to Libya', The New York Times, 02 January 2020.

36 Ben Fishman and Conor Hiney, 'What Turned the Battle for Tripoli?’, Policy Analysis/Policy Watch 3314, The Washington Institute, 06 May 2020.

37 Wehrey, 'This War Is Out of Our Hands', 31-32.

38 Jason Burke and Patrick Wintour, 'Suspected military supplies pour into Libya as UN flounders', The Guardian, 11 March 2020.

39 Metin Gurcan, 'Battle for air supremacy heats up in Libya despite COVID-19 outbreak', Al-Monitor, 06 April 2020 . 
In mid-April 2020, Libya’s internationally recognised government announced that its troops have seized control of three strategic coastal cities located between the capital, Tripoli and the Tunisian border after finally expelling Haftar's forces. Meanwhile, the UAE and the LNA forces stepped up on the attack against Tripoli and sought to counterbalance Erdoğan's Syrian deployment with sending their own foreign mercenaries. Abu Dhabi and the Wagner Group had already channelled Chadian and Sudanese fighters into the front, but later militiamen have been flown into Libya even by the Damascus-based Cham Wings Airlines to support Haftar's forces. According to a UN report, about 800 to 1,200 mercenaries from the Russian Wagner Group have been actively operating in Libya since 2018, including at least 39 Russian snipers on the front lines, while as many as 2,000 Syrians have likely been flown into Libya by Cham Wings Airlines to back Haftar. ${ }^{40}$

Thanks to the deployment of Turkish troops and air support, the GNA eventually was able to reclaim several towns in western Libya, while Haftar's forces have been forced to retreat to around Tripoli and Tarhouna. But the sudden and huge increase of the level of Turkish and Russian involvement after December 2019 has quickly led to Ankara and Moscow gaining influence on the ground, while hindering European interests and potentially sidelining the West out of any peace settlement. ${ }^{41}$

Table 1: Russian and Turkish military intervention in the Libyan civil war

\begin{tabular}{|l|l|l|}
\hline External intervener & Russia & Turkey \\
\hline Side & Haftar's LNA forces & UN-backed GNA \\
\hline Political Agenda & $\begin{array}{l}\text { Gain regional influence } \\
\text { Access to natural resources }\end{array}$ & $\begin{array}{l}\text { Maintain economic interests } \\
\text { Secure the 2019 maritime and security } \\
\text { agreement } \\
\text { Expand regional influence } \\
\text { Block Emirati expansion and Russian } \\
\text { influence }\end{array}$ \\
\hline Force & $\begin{array}{l}\text { Wagner Group (2,500) and other foreign } \\
\text { mercenary forces (3,800 Syrian fighters) } \\
\text { MiG-29, SU-24 and SU-35 fighter jets, } \\
\text { arms, equipment and other supplies } \\
\text { Parallel currency }\end{array}$ & $\begin{array}{l}\text { Bayraktar TB2 drones, Hawk missiles } \\
\text { and air defence systems } \\
\text { Jamming gear } \\
\text { Mercenary forces } \\
\text { Training and other military resources }\end{array}$ \\
\hline Stakes & $\begin{array}{l}\text { Economic gains } \\
\text { Access to southern Mediterranean } \\
\text { Prestige and great power status }\end{array}$ & $\begin{array}{l}\text { Economic gains } \\
\text { Maritime border disputes } \\
\text { Access and regional influence }\end{array}$ \\
\hline
\end{tabular}

Source: Megerisi, ‘Geostrategic Dimensions', 6.

\section{Breaking the counter-interventional cycles}

In the summer of 2020, the fighting concentrated to the areas around Jufra and the city of Sirte, while Russia continued to ship arms and sent secretly repainted combat aircraft from Syria to eastern Libya. Russia also repositioned Wagner Group fighters around Sirte,

40 David Wainer, 'Russian Mercenaries Act as 'Force Multiplier’ in Libya, UN Says', Bloomberg, 05 May 2020.

41 Megerisi, ‘Geostrategic Dimensions’, 6. 
strategic air bases across Fezzan and key oil fields. In June, Egyptian president Sisi warned that Sirte was a redline for him and he even threatened a military intervention to halt Turkey's advance to the east. But despite Sisi's warning, Turkey has been repositioning its military assets and weapons, preparing for an assault on Sirte. Meanwhile on the diplomatic front, the United States finally started pressing for a demilitarisation zone in Sirte as a means of securing a return to a political process. In this effort, Germany, the United Kingdom and the UN also took part. The U.S. ambassador to Libya engaged in shuttle talks with Ankara and Cairo, resulting in their support to a ceasefire agreement announced on August 21, 2020 by GNA Prime Minister al-Sarraj and the speaker of the eastern House of Representatives (HoR), Aguila Saleh. ${ }^{42}$

In September, Abdallah al-Thani, the prime minister of the interim government in eastern Libya, submitted the resignation of his government to Aguila Saleh amid street protests that erupted across the divided country over dire living conditions. According to the UN Support Mission in Libya the protests across the country were 'motivated by deepseated frustrations about sustained poor living conditions, shortages of electricity and water, rampant corruption, misgovernance, and a lack of service provision'. The situation clearly indicated the urgent need to lift the oil blockade imposed by tribes loyal to Haftar in the east and the return to the political process to end Libya's years long conflict. ${ }^{43}$ A few days later even Prime Minister Fayez Al-Sarraj, head of the Tripoli-based GNA, announced his intention to step down by the end of October, but weeks later he reversed his decision. On 23 October, the rival forces finally agreed on a permanent nationwide ceasefire including the departure of all foreign fighters and mercenaries from the country. This progress on the diplomatic front meant that the focus now shifted to whether the foreign actors in Libya will end supporting the warring sides and withdraw their troops. Turkey has sent approximately 4,000 Syrian mercenaries to support the UN-backed GNA, while fighters from the Russian Wagner Group have supported Haftar, and a steady flow of weaponry has been sent by the UAE in a clear breach of the UN arms embargo. ${ }^{44}$ As a part of the preliminary ceasefire agreement, Libya's rival leaders kicked off a UN-brokered prisoner exchange in December 2020, while Turkey’s Defense Minister Hulusi Akar, the military chief of staff Yasar Guler and other military commanders visited Tripoli where they were meeting with their allies in the UN-backed GNA. ${ }^{45}$ One day later senior Egyptian security officials have also visited Tripoli for the first time in years and held talks with officials from the GNA. ${ }^{46}$

42 Declan Walsh, 'Libyan Rivals Call for Peace Talks. It May Be Wishful Thinking', The New York Times, 21 August 2020.

43 Samy Magdy, 'Officials say east Libya government resigns amid protests', The Washington Post, 13 September 2020.

44 Patrick Wintour, 'Libya's rival forces sign permanent ceasefire at UN-sponsored talks', The Guardian, 23 October 2020.

45 Samy Magdy, 'UN: Libya’s rivals swap prisoners, part of cease-fire deal', AP News, 26 December 2020.

46 Al Jazeera, 'Egyptian delegation visits Libyan capital for talks with GNA', 27 December 2020. 


\section{Conclusion}

Summarising the history of Libya in recent years, we can say that the country virtually has sunk into chaos since the overthrow of Gaddafi and become divided between the internationally recognised government in Tripoli on the west, and a parallel administration on the east, which got allied to General Haftar. In a few years, Haftar has turned into a major player in Libya, thanks mainly to the backing of Egypt and the UAE which see him as a bulwark against Islamists. The Libyan civil war has intensified particularly in April 2019, after Haftar's Libyan National Army launched an offensive to capture Tripoli to oust the UN-supported GNA. But Haftar's military advances got halted due to Turkey's military intervention, which lead to a return to the negotiating table.

By the efforts of the UN, an agreement on a political solution to the crisis was reached. However, one of the fundamental challenges facing any effort to reach a political solution in Libya is the fragmentation of national authority and the deep internal divisions. It must also be noted that the Libyan conflict is constantly changing, which makes it difficult to be always aware of all the recent developments on the ground. The alliances among the actors are constantly fluctuating, while foreign interference is also a determining factor. External actors ultimately lack the trust of the Libyan society due to the fact that they are foreign. However, while Libyans view the international community with suspicion, they still appreciate the UN's efforts to reach a political solution and believe that perhaps it is the only organisation capable of solving the conflict. ${ }^{47}$

So, though the agreement on a permanent ceasefire and the latest developments in December 2020 are good signs, still, the peace process remains fraught with some major pitfalls. Besides the internal dynamics, the prospect for a durable peace is still offset by the calculations of the foreign actors and especially of the direct interveners, who continue to try to secure their political and economic interests for the long run. Maybe one of the most significant challenges of the peace process is the fact that the signatories have a limited span of control over armed and political actors on the ground. ${ }^{48}$ But we should also bear in mind that external interventions usually prolong the given conflict, while any increase in the level of its internationalisation threatens the future of Libya and its territorial integrity. ${ }^{49}$

\section{References}

'After the maritime agreement ... Turkey announces a new step in military cooperation with Libya’. Teller Report, 15 December 2019. Online: www.tellerreport.com/news/201912-15--after-the-maritime-agreement—-turkey-announces-a-new-step-in-militarycooperation-with-libya-.B1J2BOQCH.html

\footnotetext{
47 José S Vericat and Mosadek Hobrara, 'From the Ground Up: UN Support to Local Mediation in Libya', International Peace Institute, 01 June 2018, 18-20.

48 Wehrey, 'This War Is Out of Our Hands', 37.

49 'Turkey’s Growing Role in Libya', 4.
} 
Al Jazeera, 'Egyptian delegation visits Libyan capital for talks with GNA', 27 December 2020. Online: www.aljazeera.com/news/2020/12/27/egyptian-delegation-visits-libyancapital-for-talks-with-gna

Al Jazeera, 'Haftar: Libya’s UN-backed government's mandate obsolete’, 18 December 2017. Online: www.aljazeera.com/news/2017/12/18/haftar-libyas-un-backed-governmentsmandate-obsolete

Al Jazeera, 'Libya, Turkey sign deals on security and maritime jurisdictions', 28 November 2019. Online: www.aljazeera.com/news/2019/11/28/libya-turkey-sign-deals-on-securityand-maritime-jurisdictions

Al Jazeera, 'Libya’s Haftar vows to fight until Tripoli ‘militias’ defeated', 26 May 2019. Online: www.aljazeera.com/news/2019/5/26/libyas-haftar-vows-to-fight-until-tripoli-militiasdefeated

Al Jazeera, 'Timeline: Haftar's months-long offensive to seize Tripoli', 19 February 2020. Online: www.aljazeera.com/news/2020/2/19/timeline-haftars-months-longoffensive-to-seize-tripoli

Al Jazeera, 'Trump praises Haftar in apparent reversal of US policy on Libya', 20 April 2019. Online: www.aljazeera.com/news/2019/4/20/trump-praises-haftar-in-apparentreversal-of-us-policy-on-libya

Al Jazeera, 'UN envoy: 'Libya a textbook example of foreign intervention', 23 May 2019. Online: www.aljazeera.com/news/2019/5/23/un-envoy-libya-a-textbook-example-offoreign-intervention

Allahoum, Ramy, 'Libya’s war: Who is supporting whom'. Al Jazeera, 09 January 2020. Online: www.aljazeera.com/news/2020/1/9/libyas-war-who-is-supporting-whom

Anderson, Jon Lee, 'The Unravelling'. The New Yorker, 16 February 2015. Online: www. newyorker.com/magazine/2015/02/23/unravelling

BBC, 'Khalifa Haftar: The Libyan general with big ambitions', 08 April 2019. Online: www. bbc.com/news/world-africa-27492354

Burke, Jason and Patrick Wintour, 'Suspected military supplies pour into Libya as UN flounders’. The Guardian, 11 March 2020. Online: www.theguardian.com/world/2020/ mar/11/suspected-military-supplies-libya-un-cargo

Butler, Daren and Tuvan Gumrukcu, 'Turkey signs maritime boundaries deal with Libya amid exploration row’. Reuters, 28 November 2019. Online: www.reuters.com/article/ us-turkey-libya/turkey-signs-maritime-boundaries-deal-with-libyaamid-exploration-rowidUSKBN1Y213I

Caglayan, Ceyda, 'Turkey aims to sign deal with Libya over Gaddafi-era compensation'. Reuters, 10 January 2020. Online: www.reuters.com/article/us-libya-security-turkey/ turkey-aims-to-sign-deal-with-libya-over-gaddafi-era-compensation-idUSKBN1Z913A

Cumming-Bruce, Nick and Declan Walsh, 'Libya Cease-Fire Raises Hopes for Full Peace Deal'. The New York Times, 23 October 2020. Online: www.nytimes.com/2020/10/23/world/ middleeast/libya-ceasefire.html

'Final report of the Panel of Experts on Libya established pursuant to Security Council resolution 1973 (2011)'. United Nations Security Council, S/2019/914, 09 December 2019. Online: www.securitycouncilreport.org/atf/cf/\%7B65BFCF9B-6D27-4E9C-8CD3CF6E4FF96FF9\%7D/S_2019_914.pdf 
Fishman, Ben and Conor Hiney, 'What Turned the Battle for Tripoli?’ Policy Analysis/Policy Watch 3314, The Washington Institute, 06 May 2020. Online: www.washingtoninstitute. org/policy-analysis/what-turned-battle-tripoli

Gall, Carlotta, 'Turkey, Flexing Its Muscles, Will Send Troops to Libya'. The New York Times, 02 January 2020. Online: www.nytimes.com/2020/01/02/world/europe/erdogan-turkeylibya.html

Gurcan, Metin, 'Battle for air supremacy heats up in Libya despite COVID-19 outbreak'. Al-Monitor, 06 April 2020. Online: www.al-monitor.com/pulse/originals/2020/04/turkeylibya-air-supremacy-heats-up-despite-amid-coronavirus.html

'Joint Statement on U.S.-Libya Security Dialogue'. U.S. Department of State, 14 November 2019. Online: www.state.gov/joint-statement-on-u-s-libya-security-dialogue/

Kirkpatrick, David D, 'Russian Snipers, Missiles and Warplanes Try to Tilt Libyan War'. The New York Times, 05 November 2019. Online: www.nytimes.com/2019/11/05/world/ middleeast/russia-libya-mercenaries.html

Magdy, Samy, 'Officials say east Libya government resigns amid protests'. The Washington Post, 13 September 2020. Online: www.washingtonpost.com/world/africa/officials-sayeast-libya-government-resigns-amid-protests/2020/09/13/f592e25c-f605-11ea-85f75941188a98cd_story.html

Magdy, Samy, 'UN: Libya's rivals swap prisoners, part of cease-fire deal'. AP News, 26 December 2020. Online: https://apnews.com/article/africa-geneva-libya-tripoliprisoner-exchange-4071811c190fcabc6c996f10af8baab2

Malsin, Jared and Summer Said, 'Saudi Arabia Promised Support to Libyan Warlord in Push to Seize Tripoli’. The Wall Street Journal, 12 April 2019. Online: www.wsj.com/articles/ saudi-arabia-promised-support-to-libyan-warlord-in-push-to-seize-tripoli-11555077600

Megerisi, Tark, 'Geostrategic Dimensions of Libya’s Civil War'. Africa Security Brief No 37, May 2020. Online: www.jstor.org/stable/resrep24408

Polat, Ferhat, 'The trajectory of Turkey-Libya relations'. TRT World, 30 August 2019. Online: www.trtworld.com/opinion/the-trajectory-of-turkey-libya-relations-29413

Reuters, ‘Forces loyal to Libya’s U.N.-backed government receive military hardware’, 18 May 2019. Online: www.reuters.com/article/us-libya-war-arms/forces-loyal-to-libyas-unbacked-government-receive-military-hardware-idUSKCN1SO0KD

Tanchum, Michael, 'A dangerous policy of Turkish containment in the Eastern Mediterranean'. The Jerusalem Post, 10 July 2019. www.jpost.com/Opinion/A-dangerous-policy-ofTurkish-containment-in-the-Eastern-Mediterranean-595269

The Guardian, 'UN-supported Libya government and rival authority call ceasefire’, 21 August 2020. Online: www.theguardian.com/world/2020/aug/21/rival-libya-parliament-backs-unsupported-government-ceasefire

'Turkey’s Growing Role in Libya: Motives, Background and Responses', Arab Center for Research \& Policy Studies, 15 January 2020. Online: www.jstor.org/stable/resrep24490

Vericat, José S and Mosadek Hobrara, 'From the Ground Up: UN Support to Local Mediation in Libya’. International Peace Institute, 01 June 2018. Online: www.jstor.org/stable/ resrep19632.9 
Wainer, David, 'Russian Mercenaries Act as ‘Force Multiplier' in Libya, UN Says'. Bloomberg, 05 May 2020. Online: www.bloomberg.com/news/articles/2020-05-05/russianmercenaries-act-as-force-multiplier-in-libya-un-says

Walsh, Declan, 'Libyan Rivals Call for Peace Talks. It May Be Wishful Thinking’. The New York Times, 21 August 2020. Online: www.nytimes.com/2020/08/21/world/middleeast/ libya-ceasefire.html

Wehrey, Frederic, 'This War Is Out of Our Hands: The Internationalization of Libya's Post-2011 Conflicts from Proxies to Boots on the Ground'. New America, 11 September 2020. Online: www.jstor.org/stable/resrep26366

Wintour, Patrick, 'Libya's rival forces sign permanent ceasefire at UN-sponsored talks'. The Guardian, 23 October 2020. Online: www.theguardian.com/world/2020/oct/23/libya-rivalforces-sign-permanent-ceasefire-at-un-sponsored-talks

Yaakoubi, Aziz El, 'Libyan factions sign U.N. deal to form unity government'. Reuters, 17 December 2015. Online: www.reuters.com/article/us-libya-securityidUSKBNOU00WP20151217 